\title{
Association of host immunity with Helicobacter pylori infection in recurrent gastric cancer
}

\author{
Mayu Sato', Kou Miura², Chihiro Kageyama', Hiroyuki Sakae², Yuka Obayashi², Yoshiro Kawahara², \\ Osamu Matsushita ${ }^{3}$, Kenji Yokota ${ }^{1 *}$ and Hiroyuki Okada ${ }^{2}$
}

\begin{abstract}
Background: Helicobacter pylori infection is associated with the incidence of gastric cancer. Endoscopic resection has been developed as a proper technique to treat early stage of gastric cancer. However, some patients develop recurrent gastric cancer within 5 years after endoscopic treatment. The aim of the present study is to explore a biomarker for detecting people who has high risk of gastric cancer recurrence.

Methods: We analyzed the Interleukin-10 (IL-10) single nucleotide polymorphism (SNP) and IgG subclass responses to the bacteria in patients with early gastric cancer and recurrent gastric cancer.

Results: Patients with hetero-type in the 1082 SNP and CC genotype in the 592 SNP were at high risk of recurrence of gastric cancer. In patients with genotype carrying high risk of recurrence, lgG1 level tended to be higher than that in patients with other genotypes.

Conclusions: Dominance of T helper 2 (Th2) immunity controlled by IL-10 cytokine may be associated with H. pyloriassociated gastric cancer recurrence.
\end{abstract}

Keywords: Helicobacter pylori, IL-10, Single nucleotide polymorphism, IgG subclass

\section{Background}

Helicobacter pylori infection is an important factor associated with gastric cancer [1]. Incidence of $H$. pylori induced gastric cancer is dependent on geographic factors, strain diversity, and host immunological responses [2]. The incidence of gastric cancer is higher in East Asian countries than other parts of the world $[3,4]$. Therefore, several of the strain-specific features linked to high gastric cancer risk (including the cagA-ABD type of PAI, type s1 forms of vacA and babA) are present in nearly all East Asian H. pylori isolates [5-7]. However, the only minority patients were finally developed gastric cancer in the high carcinogenic $H$. pylori infected many patients. It is difficult to easily find a patient who develops gastric cancer among infected people.

Recently, endoscopic examination and resection has been established as a proper technique to treat early

\footnotetext{
*Correspondence: yokochan@md.okayama-u.ac.jp

${ }^{1}$ Graduate School of Health Science, Okayama University, 2-5-1 Shikata-cho

Kita-ku, Okayama 700-8558, Japan

Full list of author information is available at the end of the article
}

gastric cancer [8]. However, some patients developed recurrent gastric cancer within 5 years after endoscopic treatment. Previous studies reported that the incidence of recurrent gastric cancer within 5 years after endoscopic treatment is $3-10 \%[9,10]$. Clinicians recommend endoscopic examination every year, as it is difficult to distinguish patients with recurrent cancer. Therefore, identification of patients with high risk of recurrent cancer will be clinically and economically beneficial to the patients. We thought host immune response might be a potential marker to identify the patients with high risk of recurrent cancer.

H. pylori infection usually induces a strong $\mathrm{T}$ helper 1 (Th1) inflammatory response, which is characterized by cellular infiltration induced by cytokine and chemokine secretion. During the pathogenesis from chronic gastritis to gastric cancer caused by $H$. pylori infection, activated neutrophils and mononuclear cells in the host can produce pro-inflammatory cytokines, such as interleukin IL-1 $\beta$, IL-6, IL-8, and tumor necrosis factor (TNF)- $\alpha$,

C The Author(s). 2019 Open Access This article is distributed under the terms of the Creative Commons Attribution 4.0 International License (http://creativecommons.org/licenses/by/4.0/), which permits unrestricted use, distribution, and 
and anti-inflammatory cytokines such as IL-10 [11, 12]. Therefore, host immunity is closely associated with gastric cancer risk, since gastric cancer usually develops in patients after more than 30 years of $H$. pylori infection.

In the context of anti-H. pylori immunity, studies on serum anti- $H$. pylori IgG subclass have indicated that subjects with low levels of IgG2 anti-H. pylori antibody were at a risk of gastric cancer $[13,14]$, suggesting that a decreasing Th1 response is associated with developing gastric cancer. IL-10 inhibits the production of pro-inflammatory cytokines by inhibition of Th1 lymphocytes, and stimulation of B lymphocytes and Th2 lymphocytes and thus downregulates the inflammatory response [15-17].

There are three frequently detected SNPs of IL-10 promoter gene, at position-1082 A/G and-819 C/T SNPs in its proximal promoter region and at position $-592 \mathrm{~A} /$ C SNP in its 5 -flanking region, which are associate with IL-10 production and development of gastric cancer [18-20]. The IL-10 promoter was also reported to be affected by the production of IL-10 [19-21].

In this study, we analyzed the IL-10 SNPs and IgG subclass responses to the bacteria in patients with early gastric cancer and recurrent gastric cancer.

\section{Materials and methods}

\section{Patient information and DNA extraction}

Samples from the patients were collected in Okayama University hospital with patients' informed consent. Patients were treated by endoscopic mucosal resection (EMR) and followed up from 1 to 5 years. Patients' information was shown in Table 1, and clinical character of recurrent gastric cancer patients was shown in Table 2. We obtained 10 to 20 paraffin sections of stomach tissue after first EMR of 49 cases of gastric cancer (20 cases of recurrence, 29 cases of recurrence within 5 years). DNA was extracted from these paraffin sections using PAX gene ${ }^{\circ}$ Tissue DNA Kit and was stored at $-80^{\circ} \mathrm{C}$.

\section{PCR}

The following primers were designed to amplify the IL-10 promoter region containing three SNPs for PCR: IL-10

Table 1 Patient characteristics

\begin{tabular}{llll}
\hline & $\begin{array}{l}\text { Recurrent } \\
n=20\end{array}$ & $\begin{array}{l}\text { Not recurrent } \\
n=29\end{array}$ & $P$ value \\
\hline Mean age, year ( \pm SD) & $72.1(7.9)$ & $65.2(7.6)$ & 0.002 \\
Gender (F/M) & $4 / 16$ & $8 / 21$ & n. S. \\
$\begin{array}{l}\text { Observation period } \\
\text { (month) median (range) }\end{array}$ & $30(33-118)$ & $82(26-99)$ & 0.03 \\
$\begin{array}{l}\text { Endoscopic atrophy } \\
\text { (open/closed) }\end{array}$ & $19 / 3$ & $20 / 9$ & n. S \\
\hline
\end{tabular}

Table 2 Clinical character of recurrent gastric cancer patients

\begin{tabular}{lllllll}
\hline & \multicolumn{3}{l}{ Initial cancer } & \multicolumn{4}{l}{ Recurrent cancer } \\
\hline locate & $\mathrm{L}$ & $\mathrm{M}$ & $\mathrm{U}$ & $\mathrm{L}$ & $\mathrm{M}$ & $\mathrm{U}$ \\
& 6 & 12 & 3 & 6 & 8 & 6 \\
Macroscopic & Ila & $\mathrm{Ilb}$ & $\mathrm{Il}$ & Ila & Ilb & Ilc \\
Classification & 9 & 0 & 10 & 8 & 1 & 12 \\
tissue type & tub1 & tub2 & other & tub1 & tub2 & other \\
& 14 & 7 & 0 & 15 & 3 & 2 \\
\hline
\end{tabular}

forward primer (IL-10F) 5'-GTG GAA GGG GAA GGT GAA-3' and IL-10 reverse primer (IL-10R) 5'-CCC AAG ACT TCT CCT TGC TA-3'. The cycling conditions consisted of an initial single cycle of a min at $98^{\circ} \mathrm{C}$, followed by 35 cycles of $10 \mathrm{~s}$ at $98^{\circ} \mathrm{C}, 30 \mathrm{~s}$ at $60^{\circ} \mathrm{C}$, and $60 \mathrm{~s}$ at $72{ }^{\circ} \mathrm{C}$. Subsequently, the PCR product was diluted 50 times and a second PCR was performed using SNP-detection primers designed for the IL-10 region (Table 3). The cycling conditions when using primers of $819 \mathrm{~F}, 819 \mathrm{R}$, and 1082A-SNP consisted of an initial single cycle of a min at $98{ }^{\circ} \mathrm{C}$, followed by 35 cycles of $10 \mathrm{~s}$ at $98^{\circ} \mathrm{C}, 30 \mathrm{~s}$ at $66.5^{\circ} \mathrm{C}$, and $60 \mathrm{~s}$ at $72{ }^{\circ} \mathrm{C}$. The annealing temperature was changed for the SNP detection primer without changing the other conditions; it was $66.5^{\circ} \mathrm{C}$ for 1082G-SNP (same as 1082A-SNP), $57^{\circ} \mathrm{C}$ for $819 \mathrm{~T}$-SNP and 592A-SNP, 63 ${ }^{\circ} \mathrm{C}$ for $819 \mathrm{C}$-SNP, and $60^{\circ} \mathrm{C}$ for $592 \mathrm{C}$-SNP. The obtained PCR product was electrophoresed on a $1 \%$

Table 3 Primer information

\begin{tabular}{|c|c|c|c|}
\hline Primer & Sequences of primers & $\begin{array}{l}\text { Melting } \\
\text { Temperature } \\
\left({ }^{\circ} \mathrm{C}\right)\end{array}$ & $\begin{array}{l}\text { Annealing } \\
\text { Temperature } \\
\left({ }^{\circ} \mathrm{C}\right)\end{array}$ \\
\hline $\mathrm{IL}-10 \mathrm{~F}$ & $\begin{array}{l}\text { 5'-GTG GAA GGG GAA } \\
\text { GGT GAA-3' }\end{array}$ & 55.8 & 60.0 \\
\hline IL-10R & $\begin{array}{l}5^{\prime}-C C C \text { AAG ACT TCT } \\
\text { CCT TGC TA-3' }\end{array}$ & 56.3 & \\
\hline $819 F$ & $\begin{array}{l}\text { 5'-GAC TCC AGC CAC } \\
\text { AGA AGC TTA C-3' }\end{array}$ & 60.4 & a \\
\hline $819 R$ & $\begin{array}{l}\text { 5'-AGG TCT CTG GGC } \\
\text { CTT AGT-3' }\end{array}$ & 55.8 & \\
\hline 1082A-SNP & $\begin{array}{l}\text { 5'-AAC ACT ACT AAG } \\
\text { GCT TCT TTG TGA-3' }\end{array}$ & 57.3 & 66.5 \\
\hline 1082G-SNP & $\begin{array}{l}\text { 5'-AAC ACT ACT AAG } \\
\text { GCT TCT TTG TGA GG-3' }\end{array}$ & 58.9 & 66.5 \\
\hline 819 T-SNP & $\begin{array}{l}\text { 5'-TAC CCT TGT ACA } \\
\text { GGT GAT GGA ATA-3' }\end{array}$ & 57.1 & 57.0 \\
\hline 819C-SNP & $\begin{array}{l}\text { 5'-TAC CCT TGT ACA } \\
\text { GGT GAT GGA ACA-3' }\end{array}$ & 58.8 & 63.0 \\
\hline 592A-SNP & $\begin{array}{l}\text { 5'-TGA CCC CGC CGG } \\
\text { TAC-3' }\end{array}$ & 52.0 & 57.0 \\
\hline 592C-SNP & $\begin{array}{l}5^{\prime}-\mathrm{TGA} \text { CCC CGC CGG } \\
\text { TCC-3' }\end{array}$ & 54.0 & 60.0 \\
\hline
\end{tabular}

${ }^{\mathrm{a}}$ Depend on the SNP detection primer 


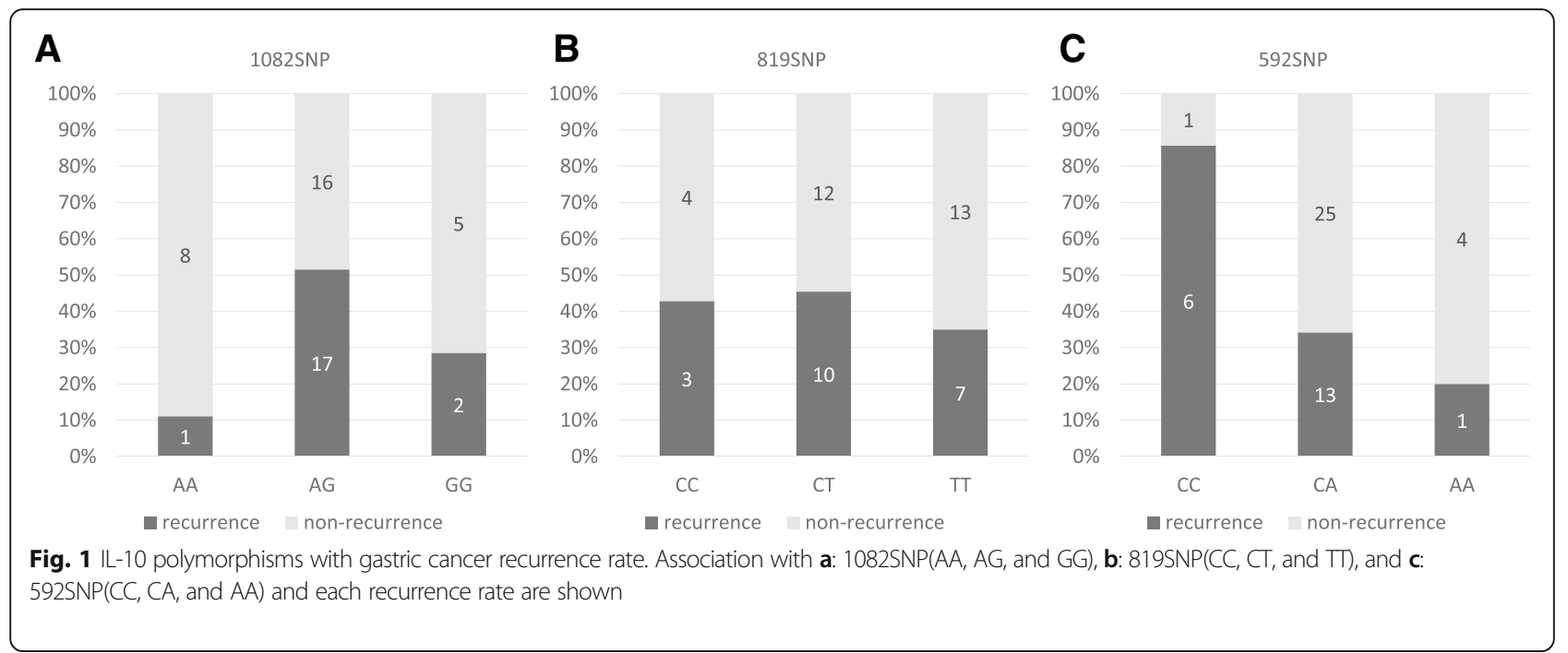

agarose gel at $100 \mathrm{~V}$ for $30 \mathrm{~min}$, stained with ethidium bromide for $10 \mathrm{~min}$, and then photographed.

\section{ELISA}

The levels of serum IgG subclass and total IgG antibodies against $H$. pylori antigen (cagA; ABD, vacA; s1c/m1, cagE+, $i c e A 1$, and $b a b A 2)$ were measured by ELISA. Ninety-six-well microtiter plates were coated with $H$. pylori lysate $(50 \mu \mathrm{g} / \mathrm{ml})$ in $100 \mu \mathrm{l}$ of $0.1 \mathrm{M}$ carbonate-bicarbonate buffer (pH 9.6) and incubated overnight at $4{ }^{\circ} \mathrm{C}$. After the wells were blocked with Phosphate Buffered Saline (PBS) containing $10 \%$ skim milk, the plates were incubated with sera containing 1:1000 of IgG and 1:100 of IgG1/2 for $2 \mathrm{~h}$ and washed with PBS containing $0.05 \%$ Tween 20. Peroxidase-labeled rabbit anti-human IgG1, IgG2, or IgG antibody (Dako Japan) was then added subsequently, and the plates were incubated for $2 \mathrm{~h}$. After the plates were washed, $1 \mathrm{mg} / \mathrm{ml}$ of o-phenylenediamine (Wako Pure Chemical) in citrate buffer ( $\mathrm{pH}$ 5.5) was added to the wells. The ODs were measured at $490 \mathrm{~nm}$ using an ELISA plate reader (Bio-Rad).

\section{Statistical analysis}

The recurrence/non-recurrence rate in each genotype was statistically analyzed using Fisher's exact probability test. Welch's t-test was used for statistical analysis of each value of the IgG subclass. In both cases, $p<0.05$ was considered significant, and a statistical software program (4 Steps Excel Statistics Ver.2, OMS, Japan) was used for all calculations.

\section{Results}

IL-10 polymorphisms with gastric cancer recurrence rate

The recurrence/non-recurrence rate of gastric cancer in the genotype for each SNP is shown in Fig. 1. The 1082 SNP was classified into homo genotype (AA, GG) and hetero genotype (AG); incidence of recurrent gastric cancer decreased in homo genotype (10\% of AA and $28 \%$ of GG) of the 1082 SNP (Fig. 1a). A statistically significant difference was found between AA and AG genotypes in the 1082 SNP $(p<0.05)$. Eight hundred and-nineteen SNP was not associated with recurrent gastric cancer (Fig. 1b). Further, in the 592 SNP, a significantly $(p<0.05)$ high rate $(86 \%)$ of CC genotype was associated with recurrent gastric cancer (Fig. 1c).

\section{Association with allele/haplotype frequencies and recurrent/non-recurrent}

Frequencies of ATA haplotype (1082A, $819 \mathrm{~T}, 592 \mathrm{~A})$ in non-recurrent gastric cancer were significantly higher than those in recurrent gastric cancer (Table 4). However, the GCC haplotype (1082G, 819C, 592C) was significantly increased in recurrent gastric cancer.

\section{IgG antibody level in recurrent gastric cancer}

The levels of total IgG and IgG subclass (IgG1 and IgG2) against $H$. pylori were measured (Fig. 2). IgG1 antibody was significantly higher in patients with recurrent cancer. To evaluate the diagnostic performance, ROC analysis was used. The ROC curves of IgG and IgG subclass are shown in Fig. 3. AUC values of total IgG, IgG1 and IgG2 were $0.58,0.98$, and 0.70 , respectively.

Table 4 Allele/haplotype frequencies of gastric cancer recurrence

\begin{tabular}{lll}
\hline & Frequencies (\%)* & \\
\cline { 2 - 3 } & ATA+ & GCC+ \\
\hline Recurrent $(n=20)$ & $11(55 \%)$ & $12(60 \%)$ \\
Non-recurrent $(n=29)$ & $22(79 \%)$ & $11(38 \%)$ \\
\hline
\end{tabular}

${ }^{*} p=0.0031$ by chi-square test 


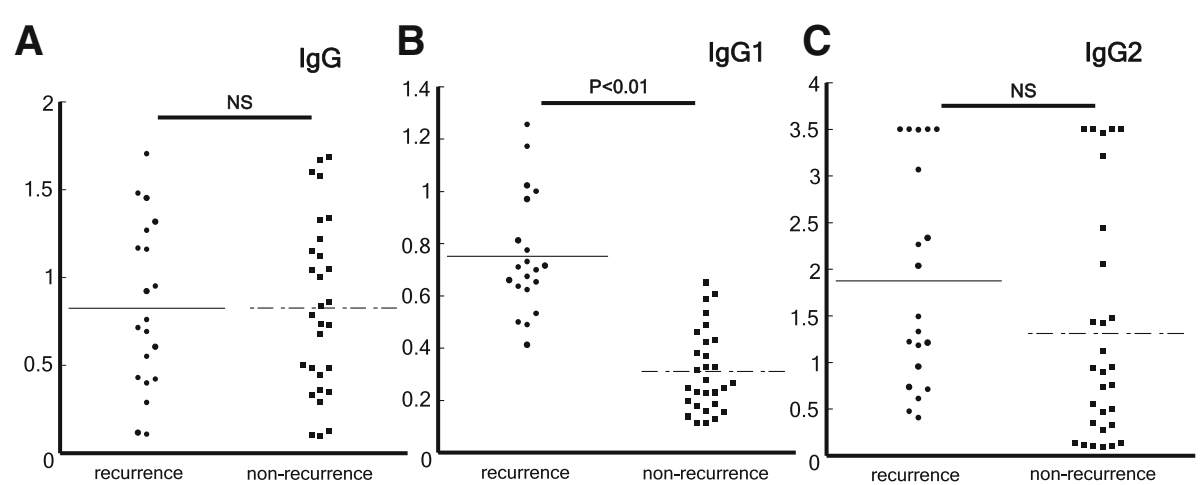

Fig. 2 lgG antibody in patients with recurrent or not-recurrent gastric cancer. IgG and lgG2 antibody levels in patients with recurrent or not-recurrent were not different. lgG1 antibody level in patients with recurrent gastric cancer was significantly higher than not-recurrent patients

\section{Discussion}

Gastric cancer remains one of the most common causes of cancer-related death. The incidence of gastric cancer prevails in a few cases among patients with $H$. pylori infection. Endoscopic resection has been established as a proper technique to treat early gastric cancer [19]. Some patients developed recurrent gastric cancer within 5 years after endoscopic treatment. Therefore, it is important to identify patients with high risk of recurrent gastric cancer. Some reports have indicated that IL-10 response and $\mathrm{T}$ helper polarity were associated with gastric cancer development. IL-10 strongly inhibits Th1 immunity, and Th1/Th2 balance affects producing IgG1/IgG2 balance. On the other hand, three SNPs of IL-10 promoter were effective to IL-10 production [21]. However, association with the SNPs and IgG1/IgG2 balance is obscure. No clear relationship was found between SNPs and IL-10 in this human study. Our study indicated that these host immunological feature and analysis of SNPs in the IL-10 promoter can be used to follow up after endoscopic resection of early gastric cancer. IgG1 (Th2 dominant antibody) response were available for prediction of recurrent gastric cancer.

\section{Conclusion}

The 1082 and 592 SNPs may be associated with gastric cancer recurrence. Patients with hetero-type in the 1082 SNP and CC genotype in the 592 SNP possess high risk of recurrence of gastric cancer. In these patients, systemic IgG1 level tended to be higher than other genotypes. Frequencies of ATA, GCC haplotype were associated with recurrent gastric cancer. Therefore, Th1/ Th2 immunity balance controlled by IL-10 may be associated with the risk of $H$. pylori-associated gastric cancer recurrence.
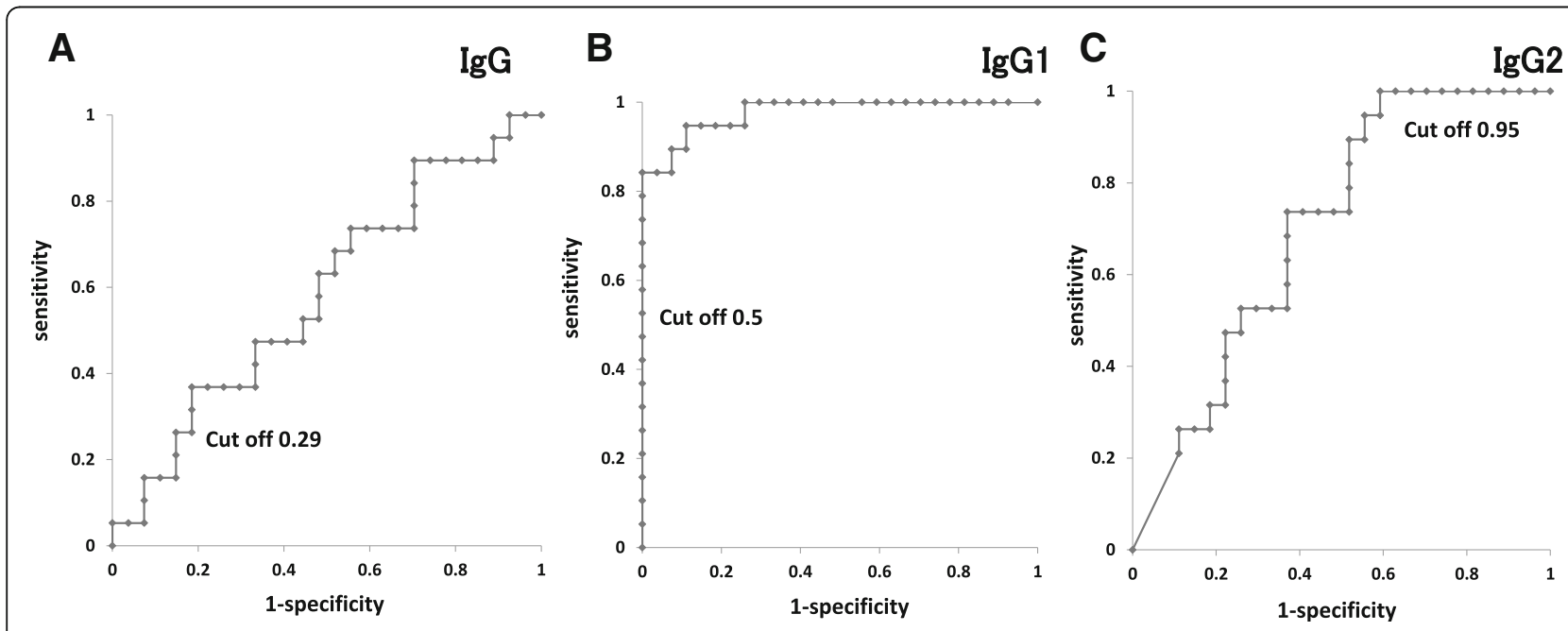

Fig. 3 The ROC curves of lgG and lgG subclass in recurrent or non-recurrent gastric cancer. Total lgG (a), lgG1 (b), and lgG2 (c) to H. pylori in patients with recurrent or non-recurrent are shown. Cut off values of IgG, IgG1, and IgG2 are 0.29. 0.5, and 0.95, respectively 


\section{Abbreviations}

DNA: Deoxyribonucleic acid; ELISA: Enzyme-Linked ImmunoSorbent Assay; EMR: Endoscopic mucosal resection; Ig: Immunoglobulin; IL: Interleukin; PAl: Plasminogen activator inhibitor; PBS: Phosphate Buffered Saline; PCR: Polymerase chain reaction; SNP: Single nucleotide polymorphism; Th: T helper; TNF: Tumor necrosis factor

\section{Acknowledgements}

We would like to thank all participants for their participation in this study.

\section{Funding}

This work was supported by grant No.20590445 and No.18 K07447 from ministry of education, culture, sports, science and technology Japan.

\section{Availability of data and materials}

The datasets used and/or analysed during the current study are available from the corresponding author on reasonable request.

\section{Authors' contributions}

MS and CK performed main experiments, KM, HS, YO, and YK collected patients' samples and information. $\mathrm{OM}, \mathrm{KY}$, and $\mathrm{HO}$ designed the experiments and wrote the manuscript. All authors read and approved the final manuscript.

\section{Ethics approval and consent to participate}

Ethical approval to carry out the study was obtained a priori from the Okayama University Ethics Committee (Number 2034). Written consent from the patient to participation this study was obtained.

\section{Consent for publication}

Not applicable.

\section{Competing interests}

The authors declare that they have no competing interests.

\section{Publisher's Note}

Springer Nature remains neutral with regard to jurisdictional claims in published maps and institutional affiliations.

\section{Author details}

${ }^{1}$ Graduate School of Health Science, Okayama University, 2-5-1 Shikata-cho Kita-ku, Okayama 700-8558, Japan. ${ }^{2}$ Gastroenterology and Hepatology, Medicine, Dentistry and Pharmaceutical Sciences, Okayama University, Okayama, Japan. ${ }^{3}$ Bacteriology, Medicine, Dentistry and Pharmaceutical Sciences, Okayama University, Okayama, Japan.

Received: 19 November 2018 Accepted: 22 January 2019

Published online: 11 February 2019

\section{References}

1. Suerbaum S, Michetti P. Helicobacter pylori infection. N Engl J Med. 2002;347: 1175-86.

2. Cover TL. Helicobacter pylori diversity and gastric Cancer risk. MBio. 2016;26: e01869-15.

3. de Martel C, Forman D, Plummer M. Gastric cancer: epidemiology and risk factors. Gastroenterol Clin North Am. 2013:42:219-40.

4. Yang L. Incidence and mortality of gastric cancer in China. World J Gastroenterol. 2006;12(1):17-20.

5. Van Doorn LJ, Figueiredo C, Mégraud F, Pena S, Midolo P, Queiroz DM, Carneiro F, Vanderborght B, Pegado MD, Sanna R, De Boer W, Schneeberger PM, Correa P, Ng EK, Atherton J, Blaser MJ, Quint WG. Geographic distribution of vacA allelic types of Helicobacter pylori. Gastroenterology. 1999;116:823-30

6. Ito Y, Azuma T, Ito S, Miyaji H, Hirai M, Yamazaki Y, Sato F, Kato T, Kohli Y, Kuriyama M. Analysis and typing of the vacA gene from cagA-positive strains of Helicobacter pylori isolated in Japan. J Clin Microbiol. 1997;35: $1710-4$

7. Lai CH, Kuo CH, Chen YC, Chao FY, Poon SK, Chang CS, Wang WC. High prevalence of cagA- and babA2-positive Helicobacter pylori clinical isolates in Taiwan. J Clin Microbiol. 2002;40:3860-2.

8. Kato M, Asaka M. Recent knowledge of the relationship between helicobacter pylori and gastric cancer and recent progress of gastroendoscopic diagnosis and treatment for gastric cancer. Jpn J Clin Oncol. 2010:40:828-37.

9. Park JC, Lee SK, Seo JH, Kim YJ, Chung H, Shin SK, Lee YC. Predictive factors for local recurrence after endoscopic resection for early gastric cancer: longterm clinical outcome in a single-center experience. Surg Endosc. 2010;24: 2842-9.

10. Hahn KY, Park CH, Lee YK, Chung H, Park JC, Shin SK, Lee YC, Kim HI, Cheong JH, Hyung WJ, Noh SH, Lee SK. Comparative study between endoscopic submucosal dissection and surgery in patients with early gastric cancer. Surgical Endoscopy Online ISSN. 2017;1432-2218:1-14.

11. Figueiredo CA, Marques CR, Costa Rdos S, da Silva HB, Alcantara-Neves NM. Cytokines, cytokine gene polymorphisms and Helicobacter pylori infection: friend or foe? World J Gastroenterol. 2004;20:5235-43.

12. EL-Omar EM, Rabkin CS, Gammon MD, Vaughan TL, Risch HR, Schoenberg JB, Stanford JL, Mayne ST, Goedert J, Blot WJ, Fraumeni JF Jr, Chow WH. Increased risk of noncardia gastric Cancer associated with Proinflammatory cytokine gene polymorphisms. Gastroenterol. 2003;124:1193-201.

13. Ren Z, Borody T, Pang G, Li L-C, Dunkley M, Clancy R. Selective reduction of anti-helicobacter pylori lgG subclass antibody in gastric carcinoma. J Gastroenterol Hepatol. 2005;20:1338-43.

14. Martinez-Becerra F, Castillo-Rojas G, Ponce de Leon S, Lopez-Vidal Y. IgG subclasses against Helicobacter pylori isolates: An important tool for disease characterization. Scand J Immunol. 2012;76:26-32.

15. Mocellin S, Marincola FM, Young HA. Interleukin-10 and the immune response against cancer: a counterpoint. J Leukoc Biol. 2005;78:1043-51.

16. Avradopoulos K, Mehta S, Blackinton D, Wanebo HJ. Interleukin-10 as a possible mediator of immunosuppressive effect in patients with squamous cell carcinoma of the head and neck. Ann Surg Oncol. 1997;4:184-90.

17. Perrin $G Q$, Johnson HM, Subramaniam PS. Mechanism of interleukin-10 inhibition of T-helper cell activation by superantigen at the level of the cell cycle. Blood. 1999;93:208-16.

18. Ni P, Xu H, Xue H, Lin B, Lu Y. A meta-analysis of Interleukin-10-1082 promoter polymorphism associated with gastric Cancer risk. DNA Cell Biol. 2012;31:582-91.

19. Xue H, Lin B, An J, Zhu Y, Huang G. Interleukin-10-819 promoter polymorphism in association with gastric cancer risk. BMC Cancer. 2012;12 102-12.

20. Xue H, Wang Y-C, Lin B, An J, Chen L, Chen J, Fang J-Y. A meta-analysis of Interleukin-10-592 promoter polymorphism associated with gastric Cancer risk. Pros One. 2012;7:e39868.

21. Rad R, Dossumbekova A, Neu B, Lang R, Bauer S, Saur D, Gerhard M, Prinz C. Cytokine gene polymorphisms influence mucosal cytokine expression, gastric inflammation, and host specific colonisation during Helicobacter pylori infection. Gut. 2004;53:1082-9.

\section{Ready to submit your research? Choose BMC and benefit from:}

- fast, convenient online submission

- thorough peer review by experienced researchers in your field

- rapid publication on acceptance

- support for research data, including large and complex data types

- gold Open Access which fosters wider collaboration and increased citations

- maximum visibility for your research: over $100 \mathrm{M}$ website views per year

At $\mathrm{BMC}$, research is always in progress.

Learn more biomedcentral.com/submission 